\section{Is preoperative haemoglobin testing justified in children undergoing minor elective surgery?}

W.L. Roy MD FRCPC, J. Lerman MD FRCPC,

B.G. McIntyre MD FRCPC
The need for preoperative haemoglobin determination before the administration of general anaesthesia to paediatric patients has long been an issue for debate. This study was undertaken to determine the value of routine preoperative haemoglobin testing in paediatric patients scheduled for minor surgery. Two thousand patients ages one month to $18 \mathrm{yr}$ scheduled for minor surgery were studied. The patients were grouped according to age, Group I $\leq y r$, Group $I I I-5 y r$, Group $I I I>5 y r$. The charts of patients whose preoperative haemoglobin concentration $(\mathrm{Hb})$ was $<100 \mathrm{~g} \cdot \mathrm{L}^{-1}$ were reviewed at a later date to determine the course of their anaesthesia and surgery. Eleven patients, all of whom were $>5$ yr $(0.5 \%)$, had a $\mathrm{Hb}<100 \mathrm{~g} \cdot \mathrm{L}^{-1}$. Of these, three patients, 27\%, had their surgery deferred, whereas the remaining eight patients, 73\%, underwent anaesthesia and surgery without complications. The three patients who were deferred returned for uneventful anaesthesia and surgery following oral iron therapy. We conclude that healthy paediatric patients five years and older scheduled for minor surgery do not require routine $\mathrm{Hb}$ determinations. Furthermore, the low incidence of anaemia and low deferral rate of anaemic children, 1-5 yr of age, lead us to question the value of preoperative $\mathrm{Hb}$ testing in this age group.

La nécessité de déterminer l'hémoglobine en préopératoire avant l'administration de l'anesthésie générale aux patients pédiatriques a êsé débartue de longue date. Celte érude fut

\section{Key words}

ANAESTHESIA: paediatric,

BLOOD: anaemia;

SURGERY: paediatric.

From the Department of Anaesthesia and the Research Institute, The Hospital for Sick Children, University of Toronto, Ontario Presented in part at the annual meeting of the Canadian Anaesthetists' Society, June 1990.

Address correspondence 10: Dr. W. L. Roy, Department of Anaesthesia, The Hospital for Sick Children, 555 University Avenue, Toronto, Ontario M5G IX8.

Accepted for publication 19th March, 1991 . entreprise afin de délerminer la valeur de tesler l'hémoglobine de routine en préopératoire chez les patients pédiatriques dont l'intervention est prévue pour une chirurgie mineure. Deux mille patients agés de un mois à 18 ans cédulés pour chirurgie mineure furent étudiés. Les patients furent divisés en groupe selon leur âge. Groupe I <I an, Groupe II I-5 ans, Groupe III $>5$ ans. Les dossiers des patients dont la concentration d' hémoglobine en préopératoire $(\mathrm{Hb})$ élait $<100 \mathrm{~g} \cdot \mathrm{L}^{-1}$ furent revus plus tard afin de déterminer l'évolution de la chirurgie et de l'anesthésie. Onze patients, tous plus âgés que 5 ans $(0,5 \%)$, avaient une hémoglobine inférieure à $100 \mathrm{~g} \cdot \mathrm{L}^{-1}$. Parmi ceux-là, trois patients, $27 \%$, ont eu la chirurgie retardée alors que les huit autres, $73 \%$, ont subi la chirurgie et l'anesthésie sans complication. Les trois patients qui ont eu leur chirurgie retardée sont relournés après le traitement avec du fer oral, ils ont subi plus tard l'anesthésie et une chirurgie sans incident. On conclut que les patients pédiatriques en bonne santé agés de cinq ans et plus, cédulés pour une chirurgie mineure, ne requièrent pas la détermination de la concentration d'hémoglobine préopératoire de routine. De plus, la faible incidence d'anémie et de retard de chirurgie chez les enfants anémiques agés de un à cinq ans nous fait douter de la valeur de la détermination routinière de la concentration d'hémoglobine préopératoire pour ce groupe d'âge.

Some authors have questioned the necessity for preoperative haemoglobin determination in paediatric patients. 1,2 Provincial law or hospital bylaws insist that the results of a haemoglobin $(\mathrm{Hb})$ analysis are entered on the patient record before anaesthesia and surgery. ${ }^{3-5}$ Furthermore, such constraints do not stipulate the minimum concentration of $\mathrm{Hb}$ that is safe for administration of anaesthesia. In fact the acceptable minimum preoperative $\mathrm{Hb}$ concentration necessary for the safe administration of general anaesthesia for elective surgery has long been an issue for debate. ${ }^{6-10}$ This study was undertaken to determine the value of routine preoperative haemoglobin testing and to establish how these results influence the conduct of anaesthesia and surgery in a paediatric ambulatory day surgery unit. 


\section{Methods}

With institutional approval, 2,000 patients ASA physical status I or 11 , aged one month to $18 \mathrm{yr}$ admitted for minor surgery in the ambulatory day care surgery were studied over a four-month period. The study group was derived from a population (urban, suburban, and regional referral patterns) with representation from a wide cross-section of ethnic, social and economic groups. Exclusion criteria included children scheduled for bone marrow biopsy, lumbar puncture and cystoscopy. In addition, children who received chemotherapy, whose preoperative blood testing was undertaken at another laboratory and those who required sickle cell testing were excluded. Capillary blood samples were obtained within two hours of surgery and the haemoglobin concentration analyzed by a Coulter Counter ${ }^{\star}$. The haemoglobin determinations were reproducible to within $\pm 2 \%$. A Hb concentration $\geq 100 \mathrm{~g} \cdot \mathrm{L}^{-1}$ was considered acceptable for the administration of general anaesthesia, although a $\mathrm{Hb}$ concentration of $<100$ $\mathrm{g} \cdot \mathrm{L}^{-1}$ did not necessarily preclude proceeding with anaesthesia and surgery. The charts of those patients with a $\mathrm{Hb}<100 \mathrm{~g} \cdot \mathrm{L}^{-1}$ were later reviewed to determine the incidence of morbidity during the perioperative period. Anaesthesia was induced by either an intravenous induction with thiopentone $\left(5 \mathrm{mg} \cdot \mathrm{kg}^{-1}\right)$ or an inhalational induction with halothane. All children received iv atropine $0.02 \mathrm{mg} \cdot \mathrm{kg}^{-1}$. Anaesthesia was maintained with $\mathrm{N}_{2} \mathrm{O} / \mathrm{O}_{2}$ and halothane by mask.

Data were analyzed utilizing Chi-square analysis and the Fisher exact tests. Statistical significance was accepted as a $P$ value of $<0.05$.

\section{Results}

The mean $( \pm S D)$ Hb concentration for the 2000 patients was $128.6( \pm 11.1) \mathrm{g} \cdot \mathrm{L}^{-1}$ (Figure). The sex distribution of patients was $63.27 \%$ male and $36.8 \%$ female. Patients were divided into three age groups after completion of the study; Group 1 - infants $(\leq 12$ mos with a mean age of $8 \pm 4$ mos), Group 2 young children ( $1-5$ yr of age with a mean age of $34.5 \pm 13.7 \mathrm{mos}$ ) and Group 3, older children ( $>5$ yr of age with a mean age of $104 \pm 40 \mathrm{mos}$ ). The incidence of a $\mathrm{Hb}$ concentration $<100 \mathrm{~g} \cdot \mathrm{L}^{-1}$ was $1.1 \%, 0.72 \%$ and $0.0 \%$ respectively in the three groups (Table I) $(P<0.05$ between Group 3 and Groups I and 2). Two patients with known diagnoses: thalassemia minor and pyruvate kinase deficiency were identified preoperatively. However, since they did not fulfil exclusion criteria, they were included. Eleven patients $(0.5 \%)$ had a $\mathrm{Hb}$ concentration $<100 \mathrm{~g} \cdot \mathrm{L}^{-1}$ : nine with $\mathrm{Hb}$ concentrations between 90 and $100 \mathrm{~g} \cdot \mathrm{L}^{-1}$, and two with $\mathrm{Hb}$ concentrations $<90 \mathrm{~g} \cdot \mathrm{L}^{-1}$. Of the nine patients, surgery was deferred in only one (11\%) (Table II) whereas of the two whose $\mathrm{Hb}<90 \mathrm{~g} \cdot \mathrm{L}^{-1}$ surgery was deferred in $100 \%$. All three children whose surgery was deferred

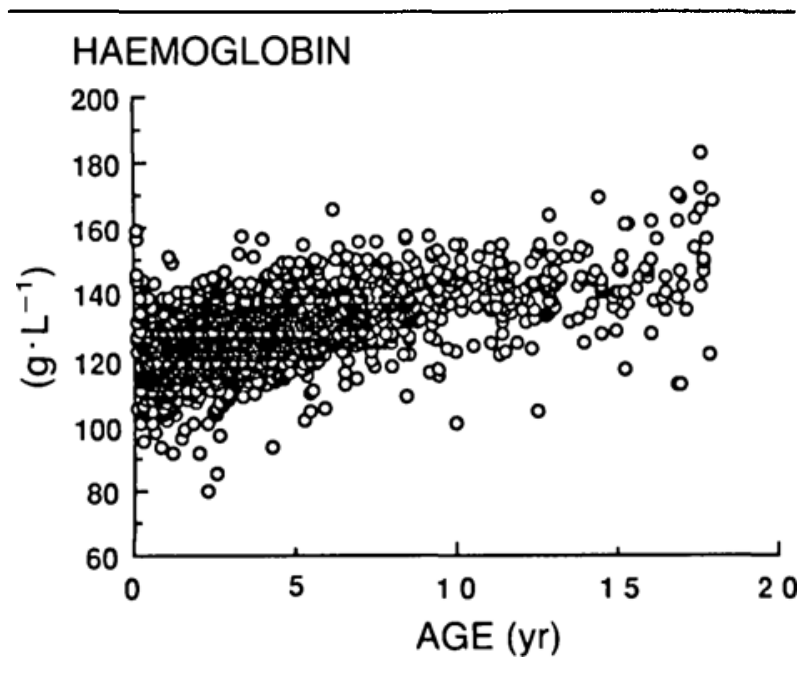

FIGURE Preoperative $\mathrm{Hb}$ values in paediatric patients aged one month to $18 \mathrm{yr}$.

TABLE I

\begin{tabular}{llcl}
\hline & Age & No. of patients & No. of parients anaemic \\
\hline Group I & $\leq 1$ yr & 257 & $3(1.1 \%)$ \\
Group II & $1-5$ yrs & 1.113 & $8(0.72 \%)$ \\
Group llI & $>5$ yrs & 1630 & $0^{*}(0.0 \%)$ \\
\hline
\end{tabular}

$* P<0.05$ compared to Groups 1 and 2 .

received iron replacement during the following three to seven months and all returned with $\mathrm{Hb}$ concentrations $>100 \mathrm{~g} \cdot \mathrm{L}^{-1}$ at the time of their subsequent anaesthesia. The eight children with a $\mathrm{Hb}<100 \mathrm{~g} \cdot \mathrm{L}^{-1}$ who underwent anaesthesia and surgery, did so without evidence of marked hypotension, tachycardia, hypothermia or any other perioperative complications. Anaesthetic technique was not modified in those children noted to have a $\mathrm{Hb}$ concentration $<100 \mathrm{~g} \cdot \mathrm{L}^{-1}$. None of these eight patients required transfusion of blood products nor were any of these individuals hospitalised postoperatively.

\section{Discussion}

Anaemia is one of the most common medical conditions encountered by the anaesthetist in clinical practice. ${ }^{6} \mathrm{~A} \mathrm{Hb}$ concentration of $100 \mathrm{~g} \cdot \mathrm{L}^{-1}$ has historically been the level below which anaesthetists question whether the patient can safely undergo anaesthesia and surgery. ${ }^{1,7,8}$ Furthermore, $100 \mathrm{~g} \cdot \mathrm{L}^{-1}$ is the level in our institution at which consideration for deferral of anaesthesia and surgery has commonly occurred. Thus a $\mathrm{Hb}$ concentration of 100 $\mathrm{g} \cdot \mathrm{L}^{-1}$ has been the minimum concentration, although a $\mathrm{Hb}$ concentration of $<100 \mathrm{~g} \cdot \mathrm{L}^{-1}$ did not necessarily preclude the administration of anaesthesia in this study. The incidence of $\mathrm{Hb}<100 \mathrm{~g} \cdot \mathrm{L}^{-1}$ in this group of patients was $0.5 \%$. We found that when the $\mathrm{Hb}$ was $90-100$ 
TABLE I]

\begin{tabular}{rlllll}
\hline Patient & Sex & $\begin{array}{l}\text { Age } \\
(\text { mos })\end{array}$ & $\begin{array}{l}H b \\
\left(g \cdot L^{-1}\right)\end{array}$ & Action taken & Comments-diagnosis \\
\hline 1 & M & 51 & 93 & Uneventful surgery & Pyruvate kinase deficiency \\
2 & M & 32 & 97 & Uneventful surgery & Thalassemia minor \\
3 & M & 30 & 85 & Case deferred & Iron deficient anaemia \\
4 & $\mathrm{~F}$ & 19 & 99 & Uneventful surgery & Iron deficient anaemia \\
5 & $\mathrm{M}$ & 24 & 92 & Uneventful surgery & Iron deficient anaemia \\
6 & $\mathrm{~F}$ & 18 & 96 & Uneventful surgery & Iron deficient anaemia \\
7 & $\mathrm{M}$ & 14 & 92 & Case deferred & Iron deficient anaemia \\
8 & $\mathrm{M}$ & 10 & 93 & Uneventful surgery & Iron deficient anaemia \\
9 & $\mathrm{M}$ & 27 & 80 & Case deferred & Iron deficient anaemia \\
10 & $\mathrm{M}$ & 8 & 98 & Uneventful surgery & Iron deficient anaemia \\
11 & $\mathrm{M}$ & 3 & 95 & Uneventful surgery & No diagnosis \\
\hline
\end{tabular}

$\mathrm{g} \cdot \mathrm{L}^{-1}$, only $11 \%$ had their surgery deferred. This is consistent with data from other centres. ${ }^{2,3}$ In contrast, both children with a $\mathrm{Hb}<90 \mathrm{~g} \cdot \mathrm{L}^{-1}$ had surgery deferred. The management of this latter group remains less certain. One can only speculate as to the outcome of the children with $\mathrm{Hb}<90 \mathrm{~g} \cdot \mathrm{L}^{-1}$ had they undergone anaesthesia and surgery without preoperative haemoglobin analysis and subsequent iron therapy.

It has been suggested that the limited capacity of blood to transport oxygen to the tissues in anaemic patients may be directly related to anaesthetic morbidity and mortality. ${ }^{8}$ However, a recent symposium concluded that "there is no evidence that mild to moderate anaemia contributes to perioperative morbidity." 10 Since, there has been no consensus on this issue, it is not surprising that a low preoperative haemoglobin concentration creates a dilemma for the anaesthetist: to proceed or not. Two compensatory mechanisms offset the limited capacity of blood to transport oxygen to the tissues in the presence of anaemia: a right shift of the oxyhaemoglobin dissociation curve and an increase in cardiac output. The magnitude of the compensatory changes, however, depends on the severity of the anaemia. For example, cardiac output increases only with $\mathrm{Hb}$ concentrations $\leq 90 \mathrm{~g} \cdot \mathrm{L}^{-1} \cdot{ }^{6}$ In a retrospective review Salem et al. ${ }^{8}$ noted a high incidence of intraoperative cardiac arrest in infants and children whose $\mathrm{Hb}$ concentration was $<100 \mathrm{~g} \cdot \mathrm{L}^{-1}$. Linman noted that children and young adults often deny any symptoms of anaemia even in the presence of extremely low $\mathrm{Hb}$ values. ${ }^{4}$ Although minor surgery may be deferred until the $\mathrm{Hb}$ concentration reaches an acceptable value in children with iron deficiency anaemia, our practice is to proceed in most cases where $\mathrm{Hb}$ is $>90 \mathrm{~g} \cdot \mathrm{L}^{-1}$. Our results, however, cannot support such a practice since only eight patients with $\mathrm{Hb}$ concentrations $<100 \mathrm{~g} \cdot \mathrm{L}^{-1}$ were anaesthetized in this study.

The primary purpose of preoperative $\mathrm{Hb}$ testing is to identify an underlying disease process that might increase perioperative morbidity and mortality. A thorough preoperative history and physical examination may be helpful in ruling out significant abnormalities which lead to anaemia. While preoperative assessment offers an opportunity to detect and treat previously undiagnosed anaemias others have found that this is not the appropriate time for widespread screening. ${ }^{2}$ What remains unclear is whether such an underlying disease process (such as malignancy, renal insufficiency and infection) could affect perioperative morbidity and mortality after minor surgery.

The aetiology of anaemia depends upon the age at the time of detection. Anaemia in the neonatal period may be attributed to recent blood loss, isoimmunization, congenital haemolytic anaemia or congenital infection. Anaemia first detected at three to six months after birth suggests a congenital disorder of haemoglobin synthesis or haemoglobin structure. " Thus, Hb testing in infancy may be justified before surgery as this may represent the first opportunity for analysis.

Anaemia is defined as a $\mathrm{Hb}$ concentration that is less than two standard deviations below the mean for the normal population. If this definition is valid, then $2.5 \%$ of the normal population are anaemic. Thus, anaemic patients may very well have $\mathrm{Hb}$ concentrations that are within the normal range (false-negative diagnoses) and some healthy patients could be classified as anaemic (false-positive diagnoses). Normal values for the concentration of haemoglobin are based on data from a superficially healthy population, a population in which minor deficiencies of iron, folate and other nutrients were not excluded. Thus, the lower limit of a normal concentration of $\mathrm{Hb}$ in children was felt to be $100 \mathrm{~g} \cdot \mathrm{L}^{-1}$. However, these minor subclinical deficiencies have now been excluded and the lowest acceptable concentration of $\mathrm{Hb}$ is $110 \mathrm{~g} \cdot \mathrm{L}^{-1}$. "The argument for investigating anaemia because it may be a sign of some underlying disease would necessitate the deferral of surgery in all paediatric 
patients with a $\mathrm{Hb}<110 \mathrm{~g} \cdot \mathrm{L}^{-1}$. However, this currently is not our practice. In addition, by setting an arbitrary limit, it is possible that some individuals with a $\mathrm{Hb}>100$ $\mathrm{g} \cdot \mathrm{L}^{-1}$ actually proceed to surgery even though additional laboratory information (mean corpuscular volume and peripheral smear) might have confirmed a diagnosis of anaemia. Should minor surgery in these patients be deferred? Mild anaemia should be diagnosed and treated with appropriate measures. However, we do not feel that such measures are necessary immediately prior to minor surgical procedures.

There is growing evidence that the aggregate expense of "little ticket" clinical laboratory tests are more devastating to the annual health budget than major capital acquisitions. ${ }^{12}$ The cost of each $\mathrm{Hb}$ determination at our hospital is $\$ 3.35$. When hidden costs (such as transportation, phlebotomy, collation of results) are added the total cost per analysis increases to $\$ 10.00$ per analysis. The amount is approximately $\$ 150,000$ per year at our hospital. The cost of widespread laboratory testing remains an issue for concern and reappraisal during periods of fiscal restraint.

Is a preoperative history and physical examination likely to detect anaemia? This may depend on several factors, including the severity of the anaemia. Identification of mildly anaemic patients by physical examination is difficult. Hackman et al. recently demonstrated that anaesthetists cannot reliably identify those paediatric outpatients who are anaemic. ' Furthermore, they suggested that, based on that evaluation, Hb determinations can be omitted from the preoperative assessment of healthy paediatric patients scheduled for minor surgery. While it may be possible for anaesthetists to detect severe anaemia, i.e., $<70 \mathrm{~g} \cdot \mathrm{L}^{-1}$, this remains to be established.

Our results demonstrated that no child $>5 \mathrm{yr}$ had a $\mathrm{Hb}$ $<100 \mathrm{~g} \cdot \mathrm{L}^{-1}$ (see Table I) consequently we must conclude that healthy children five years and older scheduled for minor surgery do not require routine pre-op $\mathrm{Hb}$ determinations. While patients $<5$ yr had a very low incidence of $\mathrm{Hb}<100 \mathrm{~g} \cdot \mathrm{L}^{-1}(1 \mathrm{l} / 2000)$ we were unable to demonstrate that anaesthetizing such patients without complication was statistically significant as the cases were so few in number. We feel, however, that in the absence of a need for sickle cell screening and in the presence of a normal history and physical examination, the preoperative $\mathrm{Hb}$ can be eliminated as a routine in patients aged $>$ l yr. In support of this practice one should consider the discomfort attached to the procurement of a blood sample from a small child and the relatively minor nature of the procedures undertaken in ambulatory surgery. Perioperative problems are very rare in the paediatric day-care setting. ${ }^{13}$ The duration of each case is generally short, the likelihood of blood loss is negligible, and the complexity of the cases is minor.
The results of this study indicate that routine $\mathrm{Hb}$ determinations are unjustified in children 5-18 yr. In addition, $\mathrm{Hb}$ testing in children $1-5 \mathrm{yr}$ of age yielded a small number of children with $\mathrm{Hb}$ concentrations $<100$ $\mathrm{g} \cdot \mathrm{L}^{-1}$ and these low $\mathrm{Hb}$ concentrations rarely altered the course of their anaesthetic management. Hence, there is no practical justification for continued testing in this age range. Because of the potential benefits of identifying anaemia in infancy, $\mathrm{Hb}$ testing may be justified in this age group alone.

We further conclude that routine preoperative $\mathrm{Hb}$ analysis rarely influences the conduct of anaesthesia (deferral or outcome) for minor surgical procedures in children ages $1 \mathrm{mo}-18 \mathrm{yr}$.

\section{References}

I Hackmann T, Steward DJ. What is the value of preoperative hemoglobin determinations in pediatric outpatients? Anesthesiology 1989; 71: All68.

$2 O^{\prime}$ Connor ME, Drasner $K$. Preoperative laboratory testing of children undergoing elective surgery. Anesth Analg 1990; 70: 176-80.

3 Government of Ontario. Public Hospitals Act. Ministry of the Attomey General 1988; 75.

4 Linman JW. Physiologic and pathophysiologic effects of anemia. N Engl J Med 1968; 279: 812-8.

5 Gillies IDS. Anaemia and anaesthesia. $\mathrm{Br} \mathrm{J}$ Anaesth 1974; 46: 589-602.

6 Allen $J B$, Allen $F B$. The minimum acceptable level of hemoglobin. Anesthesiology Clinics, 1981; 1-22.

7 Salem MR, Bennett EJ, Schweiss JF, Baraka A, Dalal FY, Collins VJ. Cardiac arrest related to anesthesia. JAMA 1975; 233: 238-41.

8 Consensus Conference. Perioperative red blood cell transfusion. JAMA 1988; 260: 2700-3.

9 Lindahl SGE. Preoperative physical assessment and preparation for surgery. In: Sumner E, Hatch DJ (Eds.). Textbook of Paediatric Anaesthetic Practice. London, Bailliere Tindall, 1989; 1-2.

10 Davis J, Sugioka K. Selecting the patient for major ambulatory surgery. Surgical Clinics of North America 1987; 67: 721-31.

11 Oski FA. Differential diagnosis of anemia. In: Nathan DG, Oski FA (Eds.). Hematology of Infancy and Childhood, 2nd ed., Philadelphia, WB Saunders Company, 1981; 289-338.

12 Grossman $R M$. A review of physician cost-containment strategies for laboratory testing. Medical Care 1983;21: 783-802.

13 Postuma R, Ferguson CC, Stanwick RS, Horne JM. Pediatric day-care surgery: a 30-year hospital experience. J Ped Surg 1987; 22: 304-7. 